\title{
Snow accumulation of a high alpine catchment derived from LiDAR measurements
}

\author{
K. Helfricht ${ }^{1,2}$, J. Schöber ${ }^{1,3}$, B. Seiser ${ }^{1,4}$, A. Fischer ${ }^{2,4}$, J. Stötter ${ }^{1,3}$, and M. Kuhn ${ }^{2}$ \\ ${ }^{1}$ alpS - Centre for Climate Change Adaptation Technologies, Innsbruck, Austria \\ ${ }^{2}$ Institute of Meteorology and Geophysics, University of Innsbruck, Austria \\ ${ }^{3}$ Institute of Geography, University of Innsbruck, Austria \\ ${ }^{4}$ Institute of Mountain Research: Man and Environment, Austrian Academy of Sciences, Innsbruck, Austria
}

Correspondence to: K. Helfricht (helfricht@alps-gmbh.com)

Received: 9 February 2012 - Revised: 9 July 2012 - Accepted: 4 November 2012 - Published: 11 December 2012

\begin{abstract}
The spatial distribution of snow accumulation substantially affects the seasonal course of water storage and runoff generation in high mountain catchments. Whereas the areal extent of snow cover can be recorded by satellite data, spatial distribution of snow depth and hence snow water equivalent (SWE) is difficult to measure on catchment scale. In this study we present the application of airborne LiDAR (Light Detecting And Ranging) data to extract snow depths and accumulation distribution in an alpine catchment.

Airborne LiDAR measurements were performed in a glacierized catchment in the Ötztal Alps at the beginning and the end of three accumulation seasons. The resulting digital elevation models (DEMs) were used to calculate surface elevation changes throughout the winter season. These surface elevation changes were primarily referred to as snow depths and are discussed concerning measured precipitation and the spatial characteristics of the accumulation distribution in glacierized and unglacierized areas. To determine the redistribution of catchment precipitation, snow depths were converted into SWE using a simple regression model. Snow accumulation gradients and snow redistribution were evaluated for $100 \mathrm{~m}$ elevation bands.

Mean surface elevation changes of the whole catchment ranges from $1.97 \mathrm{~m}$ to $2.65 \mathrm{~m}$ within the analyzed accumulation seasons. By analyzing the distribution of the snow depths, elevation dependent patterns were obtained as a function of the topography in terms of aspect and slope. The high resolution DEMs show clearly the higher variation of snow depths in rough unglacierized areas compared to snow depths on smooth glacier surfaces. Mean snow depths in glacierized areas are higher than in unglacierized areas. Maximum mean
\end{abstract}

snow depths of $100 \mathrm{~m}$ elevation bands are found between $2900 \mathrm{~m}$ and $3000 \mathrm{~m}$ a.s.l. in unglacierized areas and between $2800 \mathrm{~m}$ and $2900 \mathrm{~m}$ a.s.l. in glacierized areas, respectively. Calculated accumulation gradients range from $8 \%$ to $13 \%$ per $100 \mathrm{~m}$ elevation band in the observed catchment. Elevation distribution of accumulation calculated by applying these seasonal gradients in comparison to elevation distribution of SWE obtained from airborne laser scanning (ALS) data show the total redistribution of snow from higher to lower elevation bands.

Revealing both, information about the spatial distribution of snow depths and hence the volume of the snow pack, ALS data are an important source for extensive snow accumulation measurements in high alpine catchments. These information about the spatial characteristics of snow distribution are crucial for calibrating hydrological models in order to realistically compute temporal runoff generation by snow melt.

\section{Introduction}

In alpine head watersheds the storage of water as snow and ice has a major impact on catchment discharge. Both, the snow cover and the ice cover, have a distinct spatial distribution storing solid precipitation and affecting melt water runoff. The water reservoir ice in its manifestations as permafrost and glaciers delivers an annual runoff contribution mainly in the summer months. Changes on extent of these reservoirs act on a timescale of years to decades (Jóhannesson et al., 1989). Temporal flow retardation due to seasonal snow cover has a magnitude of hours to months 
(Braun et al., 2000; Kuhn, 2003). Areal extent of snow cover, spatial distribution of snow depth and hence SWE define seasonality and amount of runoff contribution by snow melt (Skaugen, 2007).

The catchment investigated in this study is located in the Upper Rofen valley (Tirol, Austria, $46.80^{\circ} \mathrm{N}, 10.78^{\circ} \mathrm{E}$, Fig. 1) and has a size of about $26.3 \mathrm{~km}^{2}$. It was covered by glaciers of $48.8 \%$ in 2008 and its elevation ranges from $2304 \mathrm{~m}$ a.s.l. to $3739 \mathrm{~m}$ a.s.l. This implicates a glacio-nival runoff regime characterized by large amounts of glacier meltwater runoff in summer, solid precipitation stored in a snow pack covering up to almost $100 \%$ of the area in winter and runoff generation by snow melt in spring. Two intensively studied glaciers, namely Hintereisferner and Kesselwandferner, are located in this investigation area. Data of mass balance measurements in terms of snow depth distribution and ice ablation (Kuhn et al., 1999; Escher-Vetter et al., 2009; Fischer, 2010) as well as multi-annual volume changes (Abermann et al., 2009) are the basis for hydrological modelling in this region (Kuhn and Batlogg, 1998; Braun et al., 2000).

The total amount and the spatial distribution of accumulation of solid precipitation is the key for realistic spatiotemporal modeling of meltwater runoff in alpine catchments, both from snow melt and from ice ablation. Hydrometeorological models are constructed to simulate the total amount of winter precipitation and the spatial distribution of snow accumulation. To evaluate the distribution of SWE calculated by these models, only insufficient data are available. First of all, precipitation measurements in high alpine catchments are affected by measuring errors, especially for solid precipitation in the winter season (Sevruk, 1985; Sevruk and Mieglitz, 2002). These errors can sum up to $50 \%$ of total precipitation. To account for higher precipitation rates in mountain areas, elevation gradients for precipitation are applied in hydrological modeling (Bergström, 1992; Kuhn, 2000), with the consequence, that highest precipitation rates occur at the highest elevations of the model region. In terms of solid precipitation, these additional precipitation amounts are redistributed from wind exposed ridges and steep slopes to sheltered and flatter regions, which has to be considered in snow cover modeling (Strasser, 2008). To date only the modeled area of snow cover can be evaluated extensively. This can be done using optical space-borne remote sensing techniques that deliver information in spatial resolutions up to $50 \mathrm{~m}$ (Nolin, 2011). Information on spatial distribution of snow depths and SWE is scarce. Besides snow depth measurements at several weather stations, point measurements of snow accumulation at glacierized areas exist in terms of snow probings and snow pits for calculating glacier winter mass balance (Escher-Vetter et al., 2009). Due to limited spatial coverage, these data are not applicable for the whole glacier area in a simple way.

A more favorable alternative to measure snow depths is based on application of LiDAR (Light Detecting And

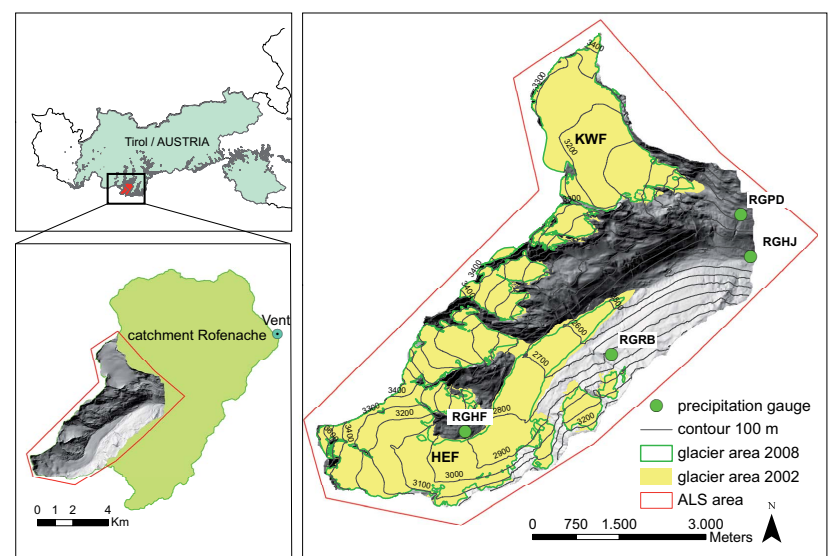

Fig. 1. Map of the investigated catchment. The village Vent, where the automatic weather station is located, the cumulative rain gauges Hochjochhospiz (RGHJ), Proviantdepot (RGPD), Rofenberg (RGRB) and Hintereisferner (RGHF) are marked. The two glaciers Hintereisferner (HEF) and Kesselwandferner (KWF) are labeled.

Ranging) technique. LiDAR, also called laser scanning, is an active remote sensing technology, producing 3 -D point data representing the observed surface in a geometrical information with a high point density and accuracy. While terrestrial laser scan measurements are spatially limited due to the maximum signal distance and topographic shading, airborne laser scanning (ALS) can be applied to larger areas (Baltsavias, 1999; Wehr and Lohr, 1999; Geist, 2005). ALS can be used in remote mountain areas, because this technique requires no external light source. For georeferencing the data no ground control points are necessary. It only needs a GPS reference station in vicinity. Relatively high costs of ALS acquisitions are compensated by the comprehensive amount of data. The investigation area can be predetermined exactly with the aim of cost reduction. Based on the 3-D point data, the so-called point cloud, digital elevation models (DEM) can be produced using interpolation algorithms (Lui, 2008). These DEMs deliver a variety of topographic parameters like slope and aspect, which are useful for hydrological modeling (Hollaus et al., 2005). Multi-temporal laser scan measurements provide the possibility to detect surface elevation changes caused by mass movements, mass loss or mass gain even in terrain that is difficult to access. Many studies analyzed the potential of these multi-temporal laser scan acquisitions in high mountain catchments investigating changes of the alpine cryosphere in terms of glacier changes (e.g. Geist and Stötter, 2007; Abermann et al., 2010; Geist and Stötter, 2009; Fischer et al., 2011). Studies about the spatial distribution of the alpine snow cover based on LiDAR measurements are mainly available for restricted areas covering only a part of mountain hillsides (e.g. Grünewald et al., 2010; Mott et al., 2010; Lehning et al., 2011). 
In this paper a set of multi-temporal ALS-measurements of the whole catchment of about $26.3 \mathrm{~km}^{2}$ is presented. The analyses were performed to answer the questions:

i. Is it possible to investigate characteristics of snow cover heterogeneity by means of ALS data?

ii. How crucial is the delimitation of unglacierized and glacierized areas?

iii. Which parameters can be extracted from snow accumulation distribution to improve hydrological modelling?

In Sect. 2 the ALS data set, additional data sources and the principles to convert snow depths into SWE are described. Section 3 highlights the results of the statistical analyses to describe some fundamental characteristics of the snow pack in the basin. Further, accumulation gradients of solid precipitation are presented and differences of ALS derived snow depths and measured snow depth at Hintereisferner are shown. The discussion (Sect. 4) will be addressed to the particularities of glacierized catchments in terms of surface elevation changes. Within the same section, the conclusions will state the importance of extensive information about the spatial distribution of seasonal water storage in the snow cover.

\section{Data and methods}

\subsection{ALS Data}

Laser scan flights are performed in the Upper Rofen valley, Ötztal Alps, Austria (Fig. 1) at the end of glacier ablation season since 2001 (Geist and Stötter, 2007; Fischer et al., 2011). Several flights were carried out between the annual measurements to record snow accumulation and snow ablation (Geist and Stötter, 2007; Spross, 2011). Within the airborne laser scan data series of the last $10 \mathrm{yr}$, currently three winter seasons (2001/2002, 2002/2003 and 2008/2009) are covered by laser scan flights. Dates of acquisitions, the corresponding identifier of the database and the point densities of the flight campaigns are shown in Table 1.

The pre-processed data were used to produce high resolution raster digital elevation models (DEM, cell size $1 \mathrm{~m}$ ) (Bollmann et al., 2011). The accuracy of the raster DEM depends on the point density and the accuracy of the laser scan point measurements. The comparison of DEM elevations from ALS data and ground control points in the Hintereisferner area shows that the vertical accuracy of the DEMs is better than $0.3 \mathrm{~m}$ (Fischer et al., 2011). The accuracy of laser measurements is influenced by the angle of the scanned slopes (Kraus, 2004). Bollmann et al. (2011) found that vertical errors increase from $\pm 0.04 \mathrm{~m}$ at slopes smaller than $35^{\circ}$ up to $\pm 1 \mathrm{~m}$ at slopes of $80^{\circ}$ and assumed an overall vertical accuracy of the DEMs of $\pm 0.15 \mathrm{~m}$ to $\pm 0.20 \mathrm{~m}$ for application of multi-temporal ALS data in alpine catchments with
Table 1. ID-number, aquisition dates and point densities of the used ALS data. Year of accumulation season, which is used later on, and the mean surface elevation change $\Delta z$ between the respective DEMs of the whole catchment are shown.

\begin{tabular}{llrlc}
\hline ID & Date & $\begin{array}{r}\text { Mean point } \\
\text { density per } \mathrm{m}^{2}\end{array}$ & $\begin{array}{l}\text { Accumulation } \\
\text { period }\end{array}$ & $\begin{array}{c}\Delta z \\
\text { in m }\end{array}$ \\
\hline hef01 & 11 Oct 2001 & 1.1 & 2002 & 2.10 \\
hef03 & 7 May 2002 & 1.2 & & \\
\hline hef07 & 18 Sep 2002 & 1.0 & 2003 & 1.97 \\
hef08 & 4 May 2003 & 0.8 & & \\
\hline hef16 & 9 Sep 2008 & 2.2 & 2009 & 2.65 \\
hef17 & 7 May 2009 & 2.4 & & \\
\hline
\end{tabular}

slopes smaller than $70^{\circ}$. For that assumption differences between differential Global Navigation Satellite System measurements and airborne laser data of about $0.07 \mathrm{~m}$ with a standard deviation of $\pm 0.07 \mathrm{~m}$ were combined with errors from ALS point to raster aggregation. The latter tends to be small on the relatively flat glacier areas without crevasses $( \pm 0.04 \mathrm{~m})$. Regarding the highly glacierized investigation area with slopes mostly smaller than $35^{\circ}$ (see Fig. 4) it is assumed here, that the vertical error of the DEM data is below $\pm 0.15 \mathrm{~m}$. While airborne laser scan data are available for an area of about $36 \mathrm{~km}^{2}$, this study uses the hydrological catchment, which was determined by a GIS watershed procedure applied on a $10 \mathrm{~m}$ grid size of the DEM corresponding to the hef16 flight (Table 1). The catchment has a size of about $26.3 \mathrm{~km}^{2}$, of which $48.8 \%$ are covered by glaciers in 2008 . Elevation ranges from $2304 \mathrm{~m}$ a.s.l. to $3739 \mathrm{~m}$ a.s.l. The areaelevation distribution of catchment area and glacier area in $100 \mathrm{~m}$ elevation bands are shown in Fig. 2.

Because significant glacier area loss occurred between 2002 and 2008, two glacier boundaries were produced using the procedure presented by Abermann et al. (2010). The glacierized area of this catchment was reduced by $8.7 \%$ between $2002\left(14.1 \mathrm{~km}^{2}\right)$ and $2008\left(12.8 \mathrm{~km}^{2}\right)$. To extract surface elevation changes, the DEMs corresponding to one accumulation season were subtracted in the order spring minus autumn. Later on dates of these DEM-differences are referred to as 2002, 2003 and 2009 (Table 1).

\subsection{Additional data}

Precipitation and temperature data are available from an automatic weather station located in Vent $\left(46.858^{\circ} \mathrm{N}\right.$, $10.013^{\circ} \mathrm{E}, 1890 \mathrm{~m}$ a.s.l.) and are shown for the analyzed accumulation seasons in Fig. 3. Four precipitation gauges located within the test site (Fig. 1) deliver a seasonal total of measured precipitation. Elevation of the precipitation gauges and measured precipitation sum of the three accumulation seasons are listed in Table 2. Whereas the weather station in Vent delivers hourly data, readings of the cumulative precipitation gauges took place coincidentally with the end of 
Table 2. Elevation and precipitation sums of the weather station Vent and the four cumulative precipitation gauges Hochjochhospiz (RGHJ), Proviantdepot (RGPD), Rofenberg (RGRB) and Hintereisferner (RGHF) of the accumulation seasons ranging from the 1st of September to the 30 April.

\begin{tabular}{|c|c|c|c|c|c|c|}
\hline \multirow[b]{2}{*}{ Year } & \multirow[b]{2}{*}{$\begin{array}{c}\text { Vent } \\
1890\end{array}$} & \multicolumn{4}{|c|}{ Cumulative precipitation gauges } & \multirow[b]{2}{*}{ ma.s.1 } \\
\hline & & $\begin{array}{c}\text { RGHJ } \\
2360\end{array}$ & $\begin{array}{c}\text { RGPD } \\
2737\end{array}$ & $\begin{array}{c}\text { RGRB } \\
2827\end{array}$ & $\begin{array}{c}\text { RGHF } \\
2970\end{array}$ & \\
\hline 2002 & 379 & 411 & 480 & 619 & 748 & $\mathrm{~mm}$ \\
\hline 2003 & 423 & 468 & 467 & 593 & 623 & $\mathrm{~mm}$ \\
\hline 2009 & 464 & 460 & 674 & 853 & 1079 & $\mathrm{~mm}$ \\
\hline
\end{tabular}

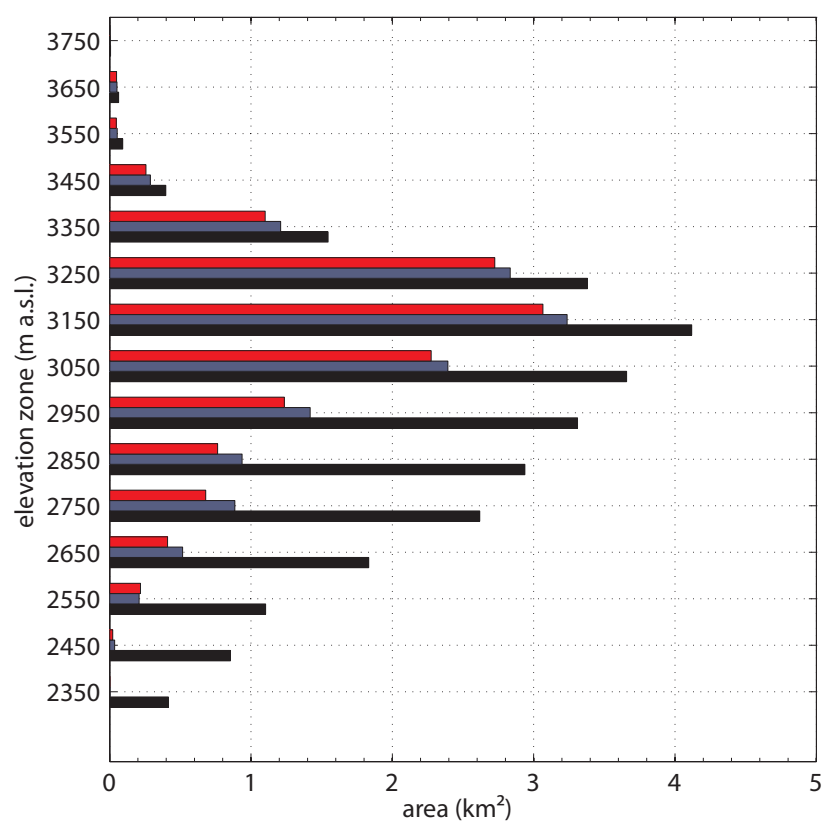

Fig. 2. Area-elevation distribution of the investigated catchment. Catchment area (black), glacier area in 2002 (gray) and glacier area in 2008 (red) are shown in steps of $100 \mathrm{~m}$ elevation bands.

accumulation season close to 30 April. These precipitation sums are the basis for further remarks on catchment precipitation in Sect. 3.

An influence of glacier dynamic processes on ALS derived snow depths at glacier surfaces can be assumed. In the investigated area annual measurements of vertical ice flow velocities are available for Kesselwandferner (Abermann et al., 2007). Less data exist to validate snow depths derived from ALS at glacier surface. In 2009, nearly at the same date of ALS data acquisition, snow sounding measurements were performed on Hintereisferner. These snow depths can be compared to snow depths derived from ALS.

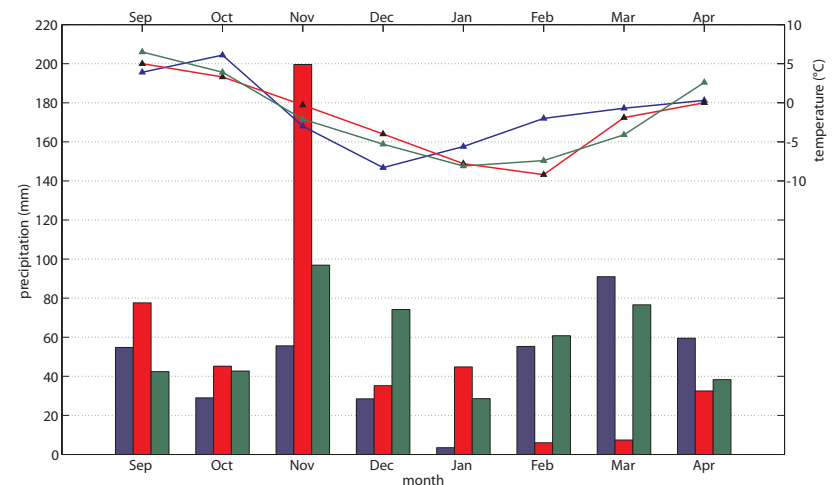

Fig. 3. Monthly precipitation sums (bars) and monthly mean temperature (lines) at the automatic weather station in Vent for the analyzed accumulation seasons 2002 (blue), 2003 (red) and 2009 (green).

\subsection{Modeling snow water equivalent and accumulation gradients}

Differences between the DEMs corresponding to one accumulation season deliver surface elevation changes $(\Delta z)$. In a first approximation these $\Delta z$ were referred to as snow depths at the end of the accumulation season. For hydrological applications snow depth has to be converted into snow water equivalent (SWE). Therefore snow density has to be known or estimated. As shown by Jonas et al. (2009), statistical relations between snow depth and snow density deliver reliable approximations. Such long time data series of snow depth and corresponding snow densities were also collected and analyzed by Schöber et al. (2012) in the Tyrolean Alps. They developed a statistical model based on one sub-dataset, which includes measurements of snow densities at the end of the accumulation season, predominantly recorded during glaciological winter mass balance measurement campaigns in the Ötztal Alps. This regression was used to calculate SWE in $\mathrm{kg} \mathrm{m}^{-2}$ by multiplying snow density $\left(\rho\left(\mathrm{kg} \mathrm{m}^{-3}\right)\right)$ by the snow depth $(h(\mathrm{~m}))$ (Eq. 1).

$\mathrm{SWE}=\rho \cdot h$

Error analysis of this statistical model show a root mean square error of $96 \mathrm{~kg} \mathrm{~m}^{-2}$ SWE. Relative errors of modeled to measured SWE decrease with increasing snow depth, whereas absolute errors increase, respectively. For more information the reader is referred to Schöber et al. (2012). The regression model was used to convert mean surface elevation changes of the $100 \mathrm{~m}$ elevation bands into SWE. Error ranges for the calculated SWE and volume of the $100 \mathrm{~m}$ elevation bands were calculated by assuming an accuracy of $\pm 0.15 \mathrm{~m}$ from ALS data and a function taking into account snow depth dependent errors of the statistical SWE-model (Fig. 6). The volume of the snow cover of one elevation band is defined as mean SWE ( $\left.\operatorname{SWE}_{\text {mean }(n)}\right)$ multiplied by the area $\left(A_{n}\right)$. The 
sum of all elevation bands (number $n$, where $n=0$ describes the lowest elevation band) gives the overall volume ( $\left.V_{\mathrm{ALS}}\right)$ of the snow cover derived by ALS data (Eq. 2).

$V_{\mathrm{ALS}}=\sum_{0}^{n}\left(\operatorname{SWE}_{\operatorname{mean}(n)} \cdot A_{n}\right)$

To obtain elevation gradients of snow accumulation, for each elevation band the measured precipitation sum of the cumulative rain gauge Hochjochhospiz $\left(P_{\mathrm{RGHJ}}\right)$ was multiplied by an accumulation gradient $\gamma$ with the power of the number of the elevation band and by the area. Equation (3) shows the calculation of overall volume by adding up the snow volume of the elevation bands.

$V_{\mathrm{mod}}=\sum_{0}^{n}\left(P_{\mathrm{RGHJ}} \cdot \gamma^{n} \cdot A_{n}\right)$

The accumulation gradient $\gamma$ was determined iteratively with the target that the modeled volume $\left(V_{\text {mod }}\right)$ equals the volume calculated from ALS data $\left(V_{\mathrm{ALS}}\right)$ in overall sum as well as in the elevation band of largest area (Eq. 4).

$\frac{V_{\mathrm{mod}}}{V_{\mathrm{ALS}}} \rightarrow 1$

\section{Results}

\subsection{Spatial variability of surface elevation changes}

Calculating the differences between the corresponding DEMs delivers a mean surface elevation change $(\Delta z)$ of the whole catchment, which is presented in Table 1 . Spatially distributed surface elevation changes were primarily referred to as snow depths. The mean $\Delta z$ of the accumulation season 2009 is about $0.5 \mathrm{~m}$ larger than the mean $\Delta z$ of the accumulation seasons 2002 and 2003. This signal is not obvious in the precipitation data of Vent and Hochjochhospiz, but more distinct at the higher precipitation measurement locations (Table 2). Precipitation sum measured at rain gauge Hintereisferner (RGHF) in 2009 has the highest increase relative to the previous investigated years $(2002,2003)$ and relative to the other rain gauges in 2009 (Table 2). Monthly distribution of precipitation and the mean monthly temperature measured at the weather station in Vent are shown in Fig. 3. It is obvious, that the largest monthly precipitation was measured in November 2002. More than twice as much precipitation was cumulated than in the other two years. A low pressure system crossing south of the alps in easterly directions caused huge amounts of orographic precipitation along the Alpine main ridge. However, the second stage of the accumulation season 2003 was very dry, which had a compensating effect at the end of winter season. In comparison to that, the accumulation season 2002 started with less precipitation, but cumulated most of the precipitation in February, March and
April. The accumulation season 2009, dominated by northwesterly flow conditions, showed an almost uniform temporal distribution of precipitation with minimum precipitation in January.

Results of the statistical analyses on elevation distribution of $\Delta z$ dependent on aspect and slope are shown in Fig. 4. The area-distribution dependent on aspect and elevation has its maximum on slopes exposed southeast at an elevation between $3100 \mathrm{~m}$ and $3200 \mathrm{~m}$ a.s.l. The maximum $\Delta z$ occurred at easterly aspects around $3000 \mathrm{~m}$ a.s.l. in the accumulation seasons 2002 and 2003. At the upper elevation bands the $\Delta z$ appeared two times larger on easterly to southeasterly slopes than on areas oriented west and northwest. In the accumulation season 2009 maximum $\Delta z$ occurred about $200 \mathrm{~m}$ higher on easterly slopes. Caused by higher energy fluxes, south exposed slopes at the lowest elevation bands remain almost snow free at the end of all three accumulation seasons.

The area distribution dependent on slope and elevation showed higher fractions of area at inclined hillsides of about $25^{\circ}$ between $2800 \mathrm{~m}$ and $3100 \mathrm{~m}$ a.s.l. Largest area fraction is located at slopes of $10^{\circ}$ to $20^{\circ}$ between $3100 \mathrm{~m}$ and $3200 \mathrm{~m}$ a.s.l. Maximum $\Delta z$ are accumulated at nearly horizontal surfaces around $2900 \mathrm{~m}$ a.s.l. With increasing elevation, occurrence of maximum $\Delta z$ is shifted towards steeper slopes. Also here maximum $\Delta z$ in 2009 occurred at higher elevations of about $3250 \mathrm{~m}$ a.s.l. Like in several other studies (e.g. Blöschl and Kirnbauer, 1992; Strasser, 2008), slopes steeper than $60^{\circ}$ show almost no snow cover.

Figure 5 shows the $\Delta z$ at $100 \mathrm{~m}$ elevation bands of unglacierized and glacierized areas and the corresponding mean standard deviations. It is clearly visible, that smaller $\Delta z$ occurred at unglacierized than at glacierized areas in all three accumulation seasons. Standard deviations of $\Delta z$ for unglacierized areas are in the same order like $\Delta z$, which increase at higher elevation bands. This is caused by the rough terrain of unglacierized areas, featuring steep slopes, ridges and depressions as well as windward and sheltered areas on small scale arrays and therefore snow redistribution by wind and gravity. A much more homogeneous distribution of $\Delta z$ can be deduced at glacierized areas by the relatively small standard deviations in comparison to the mean.

Differences of $\Delta z$ between 2002 and 2003 occur mainly at lower elevation bands. The larger $\Delta z$ in 2009 are mainly located in glacierized areas at higher elevations. Large $\Delta z$ and standard deviation at highest altitudes in 2002 are caused by ALS measurement errors in steep terrain. Maximum $\Delta z$ occurred between $2900 \mathrm{~m}$ to $3000 \mathrm{~m}$ a.s.l on unglacierized areas and between $2800 \mathrm{~m}$ to $2900 \mathrm{~m}$ a.s.l. on glacierized areas, respectively.

\subsection{Gradients of accumulation}

As described in Sect. 2.3, surface elevation changes $(\Delta z)$ of the ALS data were referred to as snow depths and converted into SWE. In the left column of Fig. 6 the graph of the mean 

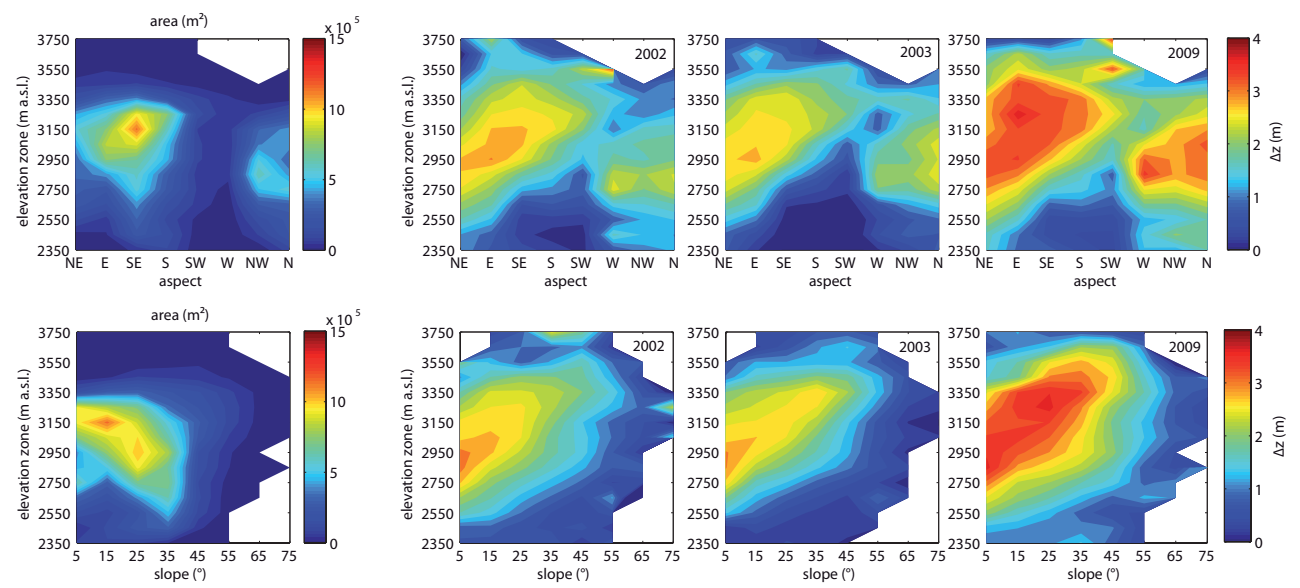

Fig. 4. Contour plots of the elevation distribution of area and surface elevation changes $(\Delta z)$ dependent on aspect and slope. In the first column the area distribution is shown. Panels 2, 3 and 4 in the first row present $\Delta z$ dependent on aspect for the accumulation seasons 2002 , 2003 and 2009. In the second row the area and $\Delta z$ dependent on slope are shown, respectively.

SWE of the $100 \mathrm{~m}$ elevation bands illustrates the vertical distribution of specific accumulation for the three seasons 2002, 2003 and 2009. The accumulation obtained from ALS data and the modeled accumulation, using the iteratively determined gradient, are shown. Precipitation measurements of the four gauge stations are plotted, too. The right column of Fig. 6 shows the volume of water equivalent calculated by multiplying the SWE by the area of the elevation bands. The lower and upper limit of the error range including the accuracy of the DEMs as well as the error of the SWE calculation are shown as dotted curves. In Table 3 the accumulation gradient $\gamma$ and the ratios between volume by ALS and modeled volume are presented. Calculated accumulation gradients of $8 \% 100 \mathrm{~m}^{-1}$ in 2003 and $13 \% 100 \mathrm{~m}^{-1}$ in 2009 seem to be dependent on the overall accumulation at the end of season.

In all three seasons mean accumulation at the lowest elevation band derived from ALS data was smaller than precipitation measurement at the cumulative precipitation gauge Hochjochhospiz. Precipitation gauges located at higher altitudes show less cumulated precipitation than accumulation at the corresponding elevation bands calculated from ALS data. This can be explained by underestimation of the cumulative precipitation caused by measurement errors dependent on fraction of solid precipitation and wind speed at the high mountain precipitation measurements (Sevruk, 1985; Sevruk and Mieglitz, 2002). Evaluated by runoff measurements, this underestimation can sum up to $30 \%$ of the total precipitation sum. In addition to local precipitation, snow can be accumulated by redistribution from wind exposed ridges and steep slopes to elevations of precipitation gauges and glacier surfaces (Kuhn, 2003; Strasser, 2008). Applying the gradient $\gamma$ starting from the precipitation measurement of Hochjochhospiz results in a increase of accumulation with increasing elevation. This vertical accumulation distribution was compared to the ALS derived specific accumulation. In the lowest
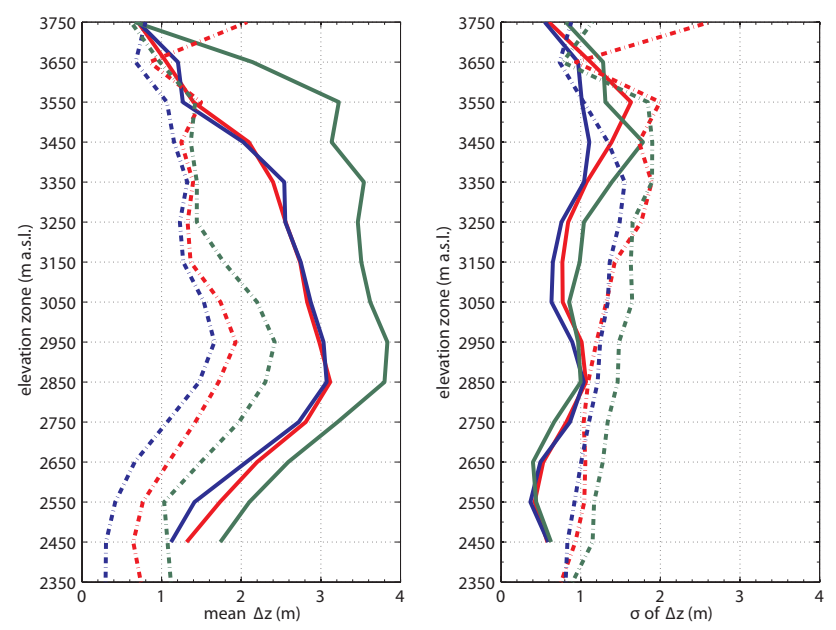

Fig. 5. Elevation distribution of the mean surface elevation change $\Delta z$ and the standard deviation $\sigma$ of surface elevation changes obtained from the DEM differences. data of the 2002 accumulation season are plotted in blue, data of 2003 in red and data of 2009 in green. Solid lines are the values of glacierized areas. Dotted lines show data of unglacierized areas.

elevation bands the modeled accumulation is larger than the accumulation obtained from ALS data. This is caused by significant melt and evaporation in these elevations even in the accumulation period. Further specific accumulation modeled by applying the gradient is smaller than accumulation derived from ALS, 2009 even smaller than precipitation measured at the higher located rain gauges. The condition for the second intersection is, that it is at the elevation band that has the largest area (see Sect. 2.3). Above this point the modeled specific accumulation is obviously larger than specific accumulation derived by ALS. Here snow redistribution processes in terms of wind and avalanches reduce the depth of 


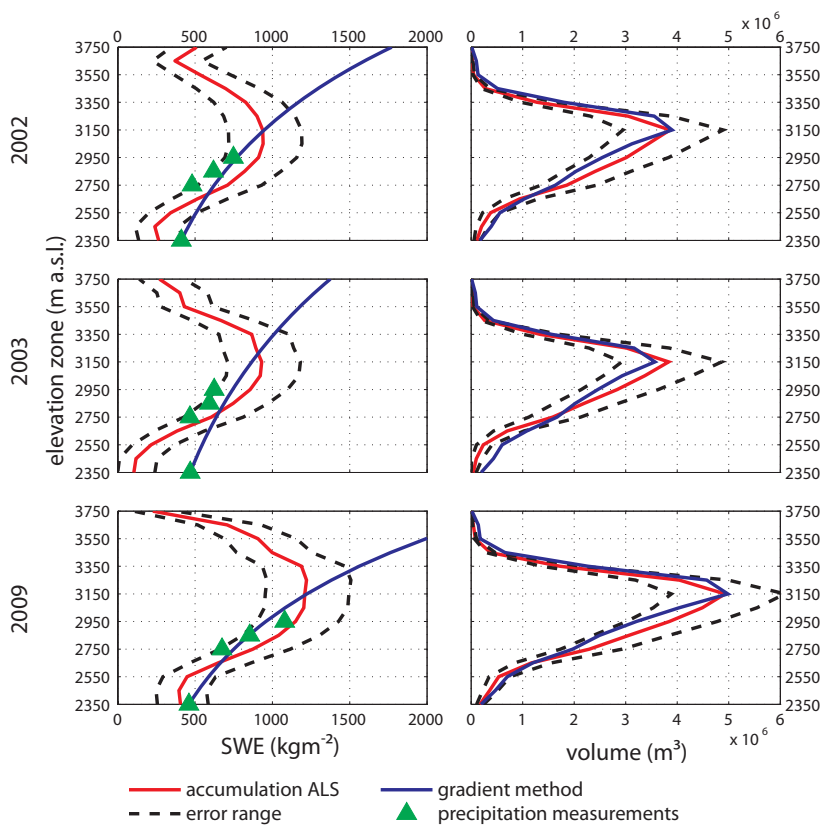

Fig. 6. Graphs of the elevation distribution of SWE in terms of specific accumulation (left column) and volume (right column) obtained from ALS data (red line), by modeling with constant gradient (blue line) and precipitation measurements (green triangle). Values are shown for the state at the end of the accumulation seasons. The black dotted curves show the upper and lower limit of error range.

Table 3. Accumulation gradients and ratios between modeled volume and volume derived from ALS measurements for catchment sum (index all) and elevation band of largest area (index max).

\begin{tabular}{ccccc}
\hline & \multicolumn{3}{c}{$\begin{array}{c}\text { Accumulation } \\
\text { gradient }\end{array}$} & \\
\cline { 2 - 3 } $\begin{array}{c}\text { Accumulation } \\
\text { period }\end{array}$ & $\gamma$ & $\% / 100 \mathrm{~m}$ & $\frac{V_{\text {mod }}}{V_{\text {ALS all }}}$ & $\frac{V_{\text {mod }}}{V_{\text {ALS max }}}$ \\
\hline 2002 & 1.11 & 11 & 1.06 & 1.01 \\
2003 & 1.08 & 8 & 1.03 & 0.93 \\
2009 & 1.13 & 13 & 1.02 & 1.01 \\
\hline
\end{tabular}

the snow cover and lead to snow accumulation in lower elevations. Considering the area elevation distribution and hence plotting the volume of the snow pack (Fig. 6, second column), it is obvious, that the specific errors at elevations with less area are not as important as realistic modeling of SWE in the altitude of largest area.

However, error range resulting from ALS measurement, DEM generation and the statistical SWE-model is largest at the elevation bands with largest area (Fig. 6). Assuming a constant error of ALS measurement, the relative error increases with decreasing snow depth. It can be assumed, that small snow depths at lowest and highest elevation bands are represented well by the ALS measurements. Higher snow depths at the elevation bands of largest area are more uncertain, but more important for the volume of the snow cover.

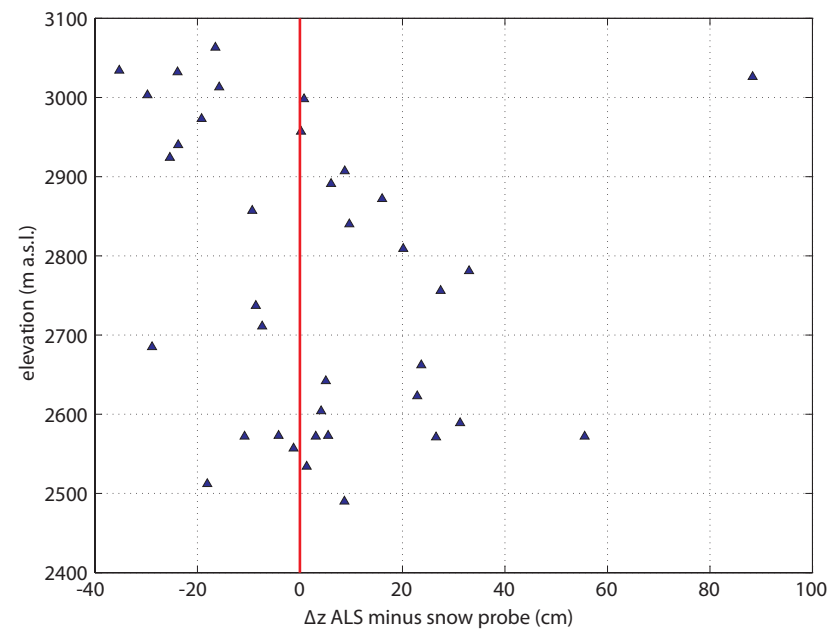

Fig. 7. Difference between ALS elevation change $\Delta z$ and measured snow depth from snow probing on Hintereisferner (HEF) at the end of accumulation season 2009.

\subsection{Estimates on vertical ice flow velocities}

Surface elevation changes derived from ALS measurements of glacier surfaces imply dynamical processes beyond the surface mass balance (Fischer et al., 2011). The vertical component of ice flow and internal subsidence of the firn layer has to be considered in studies of geodetic surface surveys in glacierized areas. Deceleration of ice flow at Kesselwandferner within the last decades lead to maximum annual vertical ice flow velocities of about $1 \mathrm{~m}$ per year (Abermann et al., 2007). Assuming that vertical ice flow velocities in the accumulation season are in the order of one third of their annual magnitude, the estimated maximum submergence and emergence velocities are about $0.35 \mathrm{~m}$ within one accumulation season. These maximum values are substantiated by comparison of ALS differences and snow soundings on Hintereisferner in May 2009 (Fig. 7). The comparison of ALS derived snow depths and snow soundings at Hintereisferner shows differences of $\pm 0.4 \mathrm{~m}$. In the upper part of the glacier ALS snow depths are lower than snow soundings, which can be explained by submergence processes. Differences at the middle elevation zones of Hintereisferner are in the same order but have reverse sign. At the glacier tongue differences are distributed around zero.

\section{Discussion and conclusions}

In this study ALS data of three accumulation seasons were used to obtain catchment characteristics in terms of spatial distribution of the snow cover and its total volume. Surface elevation changes between two corresponding DEMs at the beginning and at the end of accumulation season were interpreted as snow depths and analyzed depending on slope, aspect and elevation. Characteristically snow 
cover distributions were found in the investigated catchment. Whereas preferential snow accumulation areas are similar, snow depths were varying between the analyzed accumulation seasons. It has been shown that significant differences of snow depths exist between unglacierized and glacierized areas. This can be explained by redistribution of solid precipitation from slopes adjacent the glacier to the glacier surface. In hydrological modeling this process is important to compute glacier mass balance realistically (Kuhn, 2003). While standard deviations of snow depths at unglacierized areas are large in comparison to absolute snow depths, elevation changes at glacier surfaces are not only larger, but also more homogeneous. Discrete approaches for both areas, unglacierized and glacierized, in terms of snow cover variability are necessary in hydrological modeling.

Influence of vertical ice flow and compaction of firn layer at glacier surface are locally larger than ALS accuracy. The sign of differences between measured snow depths at Hintereisferner from snow probing and ALS derived snow depths could be explained by these processes at the upper part of the glacier. At the glacier tongue no interpretation of differences is feasible. Nevertheless, considering the overall volume of snow cover, errors by glacier dynamics must be balanced and are therefore negligible. Also vertical velocities are measured at the central flow lines and can be assumed to be getting smaller and approaching zero towards the ice.

As shown by Schöber et al. (2012) a simple regression method between snow depth and snow density leads to reasonable SWE data. Hence maps of SWE can be calculated from ALS elevation changes. These maps are like a big cumulative precipitation gauge on catchment scale, implying loss in terms of evaporation and melt water runoff. Of course, even in high alpine catchments snow melt and evaporation can occur during the accumulation season, which leads to a reduced volume of the snow cover. That means above all, that cumulative precipitation simulated by hydro-meteorological models should be at least as high as the SWE that is obtained from the ALS data at end of winter season. As a second step the snow, cumulated by continuous accumulation gradients at highest elevations of the alpine catchments, should be redistributed to lower elevation bands (Strasser, 2008). This would lead to more melt generation in the middle ablation period and would prevent too much snow accumulation at the top of the mountain ridges. Therefore the ALS data can not provide precipitation gradients, but accumulation gradients. From our experience the elevation of maximum accumulation is near $2900 \mathrm{~m}$ a.s.l. on the glaciers treated here. Due to the fact that accumulation is nearly zero at the ridges, accumulation gradients switch at elevations of maximum accumulation, which is near to $3100 \mathrm{~m}$ a.s.l. considering the whole catchment.

Catchment specific characteristics like the elevation of maximum specific accumulation, the aspect of largest accumulation and the relation between slope and snow depths can be determined by the shown method of spatial analyses of surface elevation changes obtained from ALS data. These characteristics and parameters like accumulation gradients can be used to calibrate and validate hydrological models for high mountain catchments. ALS at alpine catchments is a reliable technique to obtain volume and spatial distribution of solid precipitation on catchment scale within one accumulation season. As stated in Sect. 1, the application to large areas is limited by the costs of the ALS technique. So ALS measurements of the snow cover are more realizable in mountain catchments and highly complex terrain with heterogeneous snow distribution. Especially on glacier surfaces, future field surveys should be done simultaneously with the ALS flights to increase the knowledge about the accuracy of this method and to quantify potential processes influencing the interpretation of the surface elevation changes. The application of the presented method to other alpine catchments could improve calibration and validation processes in hydrological modeling to get a more realistic distribution of sources for runoff generation. This might have an impact on flood forecasting as well as future runoff scenarios. Long time monitoring of SWE stored in the snow cover of alpine catchments can lead to valuable conclusions about interannual variability and possible trends in volume and duration of snow cover as an impact of climate change.

Acknowledgements. This work was carried out within the frame of the alpS Project "H03 MUSICALS A - Multiscale Snow/Ice Melt Discharge Simulations for Alpine Reservoirs". The authors want to thank the Austrian Research Promotion Agency (FFG), and the TIWAG - Tiroler Wasserkraft AG, who support this project. The ALS flight campaigns analyzed in this study have been carried out within the framework of the EU Project OMEGA (Operational Monitoring of European Glacial Areas, project no: EVK2-CT-2000-00069) and the asap - Austrian Space Applications Programme ALS-X (project no: 815527). ALS data were provided by the Institute of Geography, University of Innsbruck. Many thanks to the hydrological working group of the alpS Centre for climate change adaptation technologies, who helped to improve the manuscript.

Edited by: K. Schneider and S. Achleitner

Reviewed by: two anonymous referees

\section{References}

Abermann, J., Schneider, H., and Lambrecht, A.: Analysis of surface elevation changes on Kesselwand glacier - comparison of different methods, Zeitschrift für Gletscherkunde und Glazialgeologie, 41, 147-167, 2007.

Abermann, J., Lambrecht, A., Fischer, A., and Kuhn, M.: Quantifying changes and trends in glacier area and volume in the Austrian Ötztal Alps (1969-1997-2006), The Cryosphere, 3, 205215, doi:10.5194/tc-3-205-2009, 2009.

Abermann, J., Fischer, A., Lambrecht, A., and Geist, T.: On the potential of very high-resolution repeat DEMs in glacial 
and periglacial environments, The Cryosphere, 4, 53-65, doi:10.5194/tc-4-53-2010, 2010.

Baltsavias, E.: Airborne laser scanning: basic relations and formulas, ISPRS J. Photogramm., 54, 199-214, doi:10.1016/S09242716(99)00015-5, 1999.

Bergström, S.: The HBV-model - its structure and applications, Tech. Rep. SMHI Hydrology Report No. 4, Swedish Meteorological and Hydrological Institute Narrkoping, Sweden, 1992.

Blöschl, G. and Kirnbauer, R.: An analysis of snow cover patterns in a small alpine catchment, Hydrol. Process., 6, 99-109, doi:10.1002/hyp.3360060109, 1992.

Bollmann, E., Sailer, R., Briese, C., Stötter, J., and Fritzmann, P.: Potential of airborne laser scanning for geomorphologic feature and process detection and quantifications in high alpine mountains, Z. Geomorph., Supplementary Issues, 55, 83-104, doi:10.1127/0372-8854/2011/0055S2-0047, 2011.

Braun, L., Weber, M., and Schulz, M.: Consequences of climate change for runoff from Alpine regions, Ann. Glaciol., 31, 19-25, doi:10.3189/172756400781820165, 2000.

Escher-Vetter, H., Kuhn, M., and Weber, M.: Four decades of winter mass balance of Vernagtferner and Hintereisferner, Austria: methodology and results, Ann. Glaciol., 50, 87-95, doi:10.3189/172756409787769672, 2009.

Fischer, A.: Glaciers and climate change: Interpretation of 50 years of direct mass balance of Hintereisferner, Global Planet. Change, 71, 13-26, doi:10.1016/j.gloplacha.2009.11.014, 2010.

Fischer, A., Schneider, H., Merkel, G., and Sailer, R.: Comparison of direct and geodetic mass balances on an annual time scale, The Cryosphere Discuss., 5, 565-604, doi:10.5194/tcd-5-565-2011, 2011.

Geist, T.: Application of airborne laser scanning technology in glacier research, Ph.D. thesis, Institute of Geography, University of Innsbruck, Austria, 2005.

Geist, T. and Stötter, J.: Documentation of glacier surface elevation change with multi-temporal airborne laser scanner data case study: Hintereisferner and Kesselwandferner, Tyrol, Austria, Zeitschrift für Gletscherkunde und Glazialgeologie, 41, 77106, 2007.

Geist, T. and Stötter, J.: Remote Sensing of Glaciers. Techniques for topographic, spatial and thematic mapping of glaciers, Chap. Airborne laser scanning in glacier studies, 179-194, Taylor and Francis, London, 2009.

Grünewald, T., Schirmer, M., Mott, R., and Lehning, M.: Spatial and temporal variability of snow depth and ablation rates in a small mountain catchment, The Cryosphere, 4, 215-225, doi:10.5194/tc-4-215-2010, 2010.

Hollaus, M., Wagner, W., and Kraus, K.: Airborne laser scanning and usefulness for hydrological models, Adv. Geosci., 5, 57-63, doi:10.5194/adgeo-5-57-2005, 2005.

Johannesson, T., Raymond, C., and Waddington, E.: Time-scale for adjustment of glaciers to changes in mass balance, J. Glaciol., 35, 355-369, 1989.

Jonas, T., Marty, C., and Magnusson, J.: Estimating the snow water equivalent from snow depth measurements in the Swiss Alps, J. Hydrol., 378, 161-167, doi:10.1016/j.jhydrol.2009.09.021, 2009.
Kraus, K.: Geometrische Informationen aus Photographien und Laserscanaufnahmen, Band 1, Walter de Gruyter, Berlin - New York, 2004.

Kuhn, M.: Verification of a hydrometeorological model of glacierized basins, Ann. Glaciol., 31, 15-18, doi:10.3189/172756400781820228, 2000.

Kuhn, M.: Redistribution of snow and glacier mass balance from a hydrometeorological model, J. Hydrol., 282, 95-103, doi:10.1016/S0022-1694(03)00256-7, 2003.

Kuhn, M. and Batlogg, N.: Glacier runoff in Alpine headwaters in a changing climate, Hydrology, Water Resources and Ecology in Headwaters (Proceedings of the HeadWater'98 Conference held at Meran/Merano, Italy, April 1998), IAHS P., 248, 79-88, 1998.

Kuhn, M., Dreiseitl, E., Hofinger, S., Markl, G., Span, N., and Kaser, G.: Measurements and Models of the Mass Balance of Hintereisferner, Geogr. Ann. A, 81, 659-670, 1999.

Lehning, M., Grünewald, T., and Schirmer, M.: Mountain snow distribution governed by an altitudinal gradient and terrain roughness, Geophys. Res. Lett., 38, L19504, doi:10.1029/2011GL048927, 2011.

Lui, X.: Airborne LiDAR for DEM generation: some critical issues, Prog. Phys. Geog., 32, 31-49, doi:10.1177/0309133308089496, 2008.

Mott, R., Schirmer, M., Bavay, M., Grünewald, T., and Lehning, M.: Understanding snow-transport processes shaping the mountain snow-cover, The Cryosphere, 4, 545-559, doi:10.5194/tc-4-5452010, 2010.

Nolin, A. W.: Recent advances in remote sensing of seasonal snow, J. Glaciol., 56, 1141-1150, doi:10.3189/002214311796406077, 2011.

Schöber, J., Achleithner, S., Bellinger, J., Schneider, K., Kirnbauer, R., and Schöberl, F.: Spatial and temporal characteristics of the alpine snow cover: 1. Empirical basis for regional and watershed scale applications, J. Hydrol., submitted, 2012.

Sevruk, B.: Correction of precipitation measurements: Swiss experience, WMO/TD, 104, 187-196, 1985.

Sevruk, B. and Mieglitz, K.: The effect of topography, season and weather situation on daily precipitation gradients in 60 swiss valleys, Water Sci. Technol., 45, 41-48, 2002.

Skaugen, T.: Modelling the spatial variability of snow water equivalent at the catchment scale, Hydrol. Earth Syst. Sci., 11, 15431550, doi:10.5194/hess-11-1543-2007, 2007.

Spross, M.: Die Kryosphäre Tirols im Wandel. Geostatistische Analysen zur Quantifzierung klimabedingter Veränderungen auf der Basis multitemporaler ALS-Daten, Master's thesis, Institute of Geography, University of Innsbruck, 2011.

Strasser, U.: Modelling of the mountain snow cover in the Berchtesgaden National Park, Berchtegaden National Park research report, Nr. 55, 2008.

Wehr, A. and Lohr, U.: Airborne laser scanning - an introduction and overview, ISPRS J. Photogramm., 54, 68-82, doi:10.1016/S0924-2716(99)00011-8, 1999. 